\title{
Selected Powerful Natural Antioxidants: Structure, Food Sources, Antioxidant Activities, and Important Health Benefits
}

\author{
Boris V. Nemzer ${ }^{1,2}$, Alexander Ya Yashin ${ }^{3}$, Alexander N. Vedenin ${ }^{3}$, Yakov I. Yashin ${ }^{3}$, Dmitry V. Yashunsky ${ }^{4}$, \\ Nikolay E. Nifantiev ${ }^{4} \&$ Diganta Kalita ${ }^{1}$ \\ ${ }^{1}$ Department of Research \& Development, VDF FutureCeuticals, Inc., Momence, IL 60954, USA \\ ${ }^{2}$ Department of Food Science and Human Nutrition, University of Illinois at Urbana-Champaign, Urbana, IL \\ 61801, USA \\ ${ }^{3}$ International Analytical Center of Zelinsky Institute of Organic Chemistry, Moscow 119991, Russia \\ ${ }^{4}$ Laboratory of Glycoconjugate Chemistry of Zelinsky Institute of Organic Chemistry, Moscow, Russia \\ Correspondence: Boris V. Nemzer, Department of Research \& Development, VDF FutureCeuticals, Inc., \\ Momence, IL 60954, USA. Tel: 1-815-507-1427. E-mail: bnemzer@ futureceuticals.com
}

Received: December 15, 2018 Accepted: January 4, $2019 \quad$ Online Published: January 16, 2018

doi:10.5539/jfr.v8n1p60

URL: https://doi.org/10.5539/jfr.v8n1p60

\begin{abstract}
Numerous epidemiological studies indicate that consumption of antioxidant-rich foods is beneficial to human health and reduces the risks of dangerous diseases and premature aging. Among natural antioxidants some stand out for their powerful activity and health benefits and they are epigallocatechin gallate, quercetin, curcumin, resveratrol, hydroxytyrosol, astaxanthin, lycopene, dihydroquercetin, and lignans. Preclinical, clinical, and therapeutic studies of these antioxidants in their pure form or in their combination have shown positive health benefits. This review highlights basic information and interesting findings with their source, structure, antioxidant properties, and potential health benefits to human.
\end{abstract}

Keywords: natural antioxidants, foods, antioxidant activity, bioavailability, health benefits

\section{Introduction}

Epidemiological studies have demonstrated that consumption of antioxidant rich foods and beverages reduces the risks of dangerous diseases and premature aging in human (Preedy, 2010; Klein, 2014; Preedy, 2014; Waltson, Preedy, \& Zibadi, 2014; Preedy, 2014; Yashin, Vedenin, \& Yashin, 2016; Chu, 2012). Under excessive oxidative stress, the natural human antioxidant system is not able to neutralize the deleterious effects of free radicals which could damage cellular DNA, lipids, proteins, and other biomolecules that led to the development of chronic diseases and premature aging. Antioxidants are required to scavenge free radicals and prevent their actions in vivo to protect cells and tissues.

Several dietary antioxidants are primarily originated from fruits, vegetables, berries, spices, nuts, tea, coffee, cocoa, and red wine. Food databases of the total antioxidant content in various foods have been created during recent years and the intake of natural antioxidants in different countries have been evaluated (Yashin et al., 2010; Nemzer, Yashin, \& Yashin, 2013; Wu et al., 2004). Halvorsen et al., (2006) evaluated and ranked 1120 food samples from USDA for total antioxidant activity and found that top 50 antioxidant rich foods are occupied by spices, fruits, vegetables, berries, chocolate, and nuts (Halvorsen et al., 2006). Along with proteins, fats, carbohydrates, vitamins, and trace elements, natural antioxidants are recognized as an important component of a healthy diet. In fact, antioxidant potential plays significant role in the marketing of antioxidant rich superfoods.

An antioxidant functions by transferring electrons, donating hydrogen, reducing peroxides, quenching singlet oxygen and superoxide, and chelating metal ion (Brewer, 2011; Nimese \& Pal, 2015). Several in vitro antioxidant assays have been developed in continuation of the searching and identifying natural and safe antioxidants. Due to their differences in structures and reaction mechanisms of free radical several assays have been used to measure the antioxidant activities. For instance, ORAC (oxygen radical absorbance capacity), DPPH (diphenylpicrylhydrazyl), ABTS (2,2-azobis-(3-ethyl-benzothiazoline-6-sulfonate), (FRAP (ferric-reducing antioxidant power), superoxide anion radical scavenging, phospholipid peroxidation assays have been widely used as in vitro tests to determine the antioxidant potential for synthetic and natural products. In 
most of the studies multiple assays were adopted to test the antioxidant capacity of number of plant extracts and phytochemicals as single antioxidant assay may not give conclusive information on antioxidant potential.

Antioxidant studies of fruits, vegetables, beverages, and functional foods have been attracting continuously for long time and the number of reports in this area increasing every year. Most of these reports covered the polyphenols content and their effect on antioxidant activities with their mechanism of action using appropriate antioxidant assays. These studies indicated the strong antioxidant activities arose due to the presence of certain polyphenolic and/or synergism of several antioxidant compounds (Brewer, 2011; Wu et al., 2004; Oroian \& Escriche, 2015). Plant extracts and food matrices contain complex mixtures of polyphenols. Likewise, numerous compounds from these extracts have been reported to have potential antioxidant activities, many plant extract and food matrices are poorly characterized. However, among these natural antioxidant compounds very few have strong antioxidant activities. In this review we describe an overview of selected most powerful natural antioxidant compounds with their structure, source, bioavailability, antioxidant properties, and potential health benefits.

\section{Powerful Natural Antioxidants}

Antioxidants are subgrouped into three major groups such as polyphenols, vitamins, and carotenoids. In addition to these general group of antioxidant compounds some other nonphenolic compounds also showed promising antioxidant potential. Polyphenols are ubiquitous in plant species and more than 8000 phenolic compounds have been reported, many of which are major constituents of foods. Classification of polyphenols are based on the number of phenol rings and the nature of binding the rings to one another. Major groups of polyphenols constitute flavonoids, phenolic acids, phenolic alcohol, stilbenes, and lignans. Among them most common polyphenols are flavonoids that provide color and flavor to fruits and vegetables. Flavonoids are subgrouped into flavones (e.g., luteolin, tangeritin), flavonols (e.g., catechin, quercetin), flavanones (e.g., butin, naringin), flavanols (e.g., catechin, epicatechin gallate, epigallocatechin), anthocyanidins (e.g., petunidin pelargonidin, malvidin), and isoflavones (e.g., genistein, daidzein). Natural flavonoids exist as glycosides (sugar is attached) as well as aglycones forms. Most of the polyphenols exist in conjugated forms with one or more sugar residue linked to hydroxyl group.

The antioxidant potential of natural antioxidant depends on the structural composition of free hydroxyl (-OH) group in the flavonoid skeleton. Flavonoids with multiple hydroxyl groups show higher antioxidant activities compared to flavonoids with single hydroxyl group. However steric relationship and lipid/hydrophilic phase equilibrium also plays critical role towards the antioxidant activities (Brown \& Kelly, 2007). The general mechanism of antioxidant activities of polyphenolic compounds undergoes inactivation of free radicals via transfer of hydrogen atom and electron. However, efficiency of in vivo and in vitro antioxidant activities depends on various factors such as structure, source, bioavailability of antioxidants, genetic, environmental, and physiological conditions.

Based on the reports on antioxidant activities of natural antioxidants very few have super strong antioxidant activity and have been used by consumers worldwide. We have listed nine such natural antioxidant compounds in the Table1 including their structure and major sources.

\subsection{Epigallocatechin Gallate (EGCG) and other Catechins}

Catechins are one of the major flavonoid compounds that constitute strong antioxidant activities. The common structural unit of catechin composed of a C15 (C6-C3-C6) skeleton containing 3 ring (A, B, and C) phenolic compounds where a double ring attached to a third ring (each phenyl ring has multiple hydroxyl group) by a single bond. In addition to the significant antioxidant properties tea catechins, they have the novel characteristic of trapping reactive carbonyl species. The ring A of the catechins is responsible for reactive carbonyl species trapping, and ring B contribute towards antioxidation (Wang \& Ho, 2009).

Green tea is the major source of catechins containing15 to 20\% of dry weight (Yashin, Vedenin, \& Yashin, 2016; Juneja, Kapoor, Okubo, \& Rao, 2013). Black tea and oolong tea which are fully and partially fermented tea respectively, also contain a significant level of catechin compounds. However, due to differences in manufacturing process polyphenol contents in black tea and oolong tea are different from green tea. Nonfermented green tea products contain higher levels of total phenolics and catechins. ECCG is reported as the main active constituent of green tea which comprises 50 to $80 \%$ of the total catechin content. In addition to ECCG epicatechin gallate (ECG), epigallocatechin (EGC), epicatechin (EC) and catechin (C) are some other catechin available in tea. Other sources of catechins include grapes, red wine, cocoa, and dark chocolate. Dry red wine contains catechin $(191 \mathrm{mg} / \mathrm{L})$ and epicatechin $(82 \mathrm{mg} / \mathrm{L})$ at levels that are 4 to 6 times higher than in white wine. Cocoa and dark chocolate contain catechin and epicatechin only. In cocoa they make up to $40 \%$ of the total 
polyphenol content. Catechins are also found in white and yellow tea which are not fermented.

Number of studies indicated catechin extract and purified fraction from all these natural resources exhibited significant antioxidant activity in vivo, in vitro, and in clinical studies. Recently He et al., (2018) studied the antioxidant potential of some catechins and reported that epigallocatechin gallate had the highest radicalscavenging activity and significant role to retard the ROS production because of the presence of hydroxyl and galloyl groups (He, Xu, Yang, \& Wang, 2018). Grazseik et al., (2018) reported in a study that catechins showed the highest activities in ABTS-scavenging capacity and FRAP assay (Grazseik, Naparlo, Bartosz, \& Sadowska-Bartosz, 2018).

Green teas are being consumed for medicinal benefits for thousands of years. In recent decades, the benefits of green tea and EGCG alone were specifically studied in hundreds of epidemiological studies. Large body of literature are available on the health benefits of tea (Preedy, 2013; Powell, 2015; Yashin, Yashin, \& Nemzer, 2012; Hayat, Iqbal, Malik, Bilal \& Musthag, 2015; Wiejska, 2014). Green tea polyphenols are reported to play significant role in the prevention of cardiovascular diseases (Arab, Khan, \& Lam, 2013; Grassi et al., 2013; Hodgson, 2008; Keske et al., 2015; Pang et al., 2015), reduction in low-density lipoprotein oxidation (Grassi et al., 2013), reduction in the risk of stroke and infarction (Hodgson, 2008), reduction of cholesterol levels (Kajimoto, Kajimoto, \& Kakuda, 2003), and decrease in blood pressure (Liu et al., 2013). Several studies indicated the anticancer activities against the cancer in prostate, stomach, intestine, liver, breast, rectal, lung, kidney, and pancreatic (Brausi, Rizzi, \& Bettuzzi, 2008; Borreli, Capasso, Russo, \& Ernst, 2004; Myung et al., 2009; Butler et al., 2015; Baba et al., 2012; Ogunleye, Xue, \& Michels, 2010; Li, Yin, Wang, \& Jiang, 2014; Arab \& Il'yasova, 2003; Li et al., 2008; Carvalho, Jerónimo, Valentăo, Andrade, \& Silva, 2010; Shankar, ganapathy, Hingorani, \& Srivastava, 2008). Sabu et al., (2002) have reported that administration of green tea polyphenols increased glucose tolerance significantly when administered to normal rat and reduced serum glucose level in alloxan diabetic rats (Sabu, Smitha, \& Kuttan, 2002). Moreover, green tea polyphenols containing catechin acted against chronic diseases (Balentine \& Paetau-Robinson, 2000), hepatitis C (Lin et al., 2013) and B (Xu, Wang, Deng, Hu, \& Wang, 2008), Epstein-Barr virus (Liu et al., 2013), influenza virus (Matsumoto, Yamada, Takuma, Niino, \& Sagesaka, 2011), bacterium Helicobacter pylori (Stoicov, Saffari, \& Houghton, 2009), and inflammation (Chatterjee, Chandra, Dey, \& Bhattacharya, 2012; Sing, Akhtar, \& Haqqi, 2010). It helped in protection from obesity (Rains, Agarawal, \& Maki, 2011), improvement of mental abilities (Ide et al., 2014), beneficial effects in oral diseases (Kushiyama, Shimazaki, Murakami, \& Yamashita, 2009), protection against Alzheimer's disease (Dragicevic et al., 2011), protection against urinary tract infections (Reygaert \& Jusifi, 2013), human skin protection against UV radiation (Camouse et al., 2009). Interestingly galloyl moiety in catechins plays significant role towards the beneficial effects including lipid lowering effect (Ikeda, Tsuda, \& Suzuki, 2005).

\subsection{Quercetin}

Quercetin is one of the most common flavonol compounds that comprised of an alcohol group on the C ring of flavonoid C15 skeleton. Quercetin is characterized by the presence of an ortho-dihydroxy or catechol group, a 2, 3-double bond, and 3, 5 hydroxyl substitution (Bors, Heller, Michel, \& Saran, 1990). These special structural properties have featured quercetin, as an excellent antioxidant agent (Silva, Santos, Caroco, Rocha, Justino, \& Mira, 2002; Rietjens, Boersma, van der Woude, Jeurissen, Schutte, \& Alink, 2005).

Quercetin is highly abundant in fruits and vegetables. Onion is reported to have the highest level of quercetin (approx. $300 \mathrm{mg} / \mathrm{kg}$ ) (Beecher, 1999). Other vegetables, such as broccoli, kale, apples, cranberries, yellow bell peppers, celery, tomatoes, blueberries, blackberries, raspberries, black currants, cherries, and apricots also have significant range of quercetin. Processing and storage could change the content of quercetin in food matrices. Ikou et al., (2001) found that frying and boiling cooking methods reduces the level of quercetin due to the thermal degradation and leaching to the water (Ikou et al., 2001). Long-term storage of foods was found to change their quercetin content. Efforts have been directed for enhancing nutraceutical bioaccessibility for quercetin. In order to improve the bio-accessibility of this hydrophobic nutraceutical formulated emulsion-based excipient food were prepared (Chen et al., 2018). Quercetin encapsulated in nanoparticle, for instance Zein/chitosan nanoparticles (ZCPs-Q) have also been prepared which improved its stability and water solubility and intracellular antioxidant activities (Ma, Yu, Yin, Tang, \& Yang, 2018).

Quercetin shows potential anticarcinogenic, hepatoprotective, bacteriostatic, cardioprotective, anti-inflammatory, heavy metals chelating, and antioxidant properties (Russo, Spagnuolo, Tedesco, Billoto, \& Russo, 2012). The chemical structure of quercetin confers it an outstanding antioxidant ability according to Bors et al., (1990) (Bors, Heller, Michel, \& Saran, 1990). Quercetin protects DNA from oxidative damage occurred by the attack of free 
radicals. The major beneficial health effects of quercetin-containing products are: inhibition of oxidative stress by protecting DNA molecules (Russo, Spagnuolo, Tedesco, Billoto, \& Russo, 2012 ), anti-inflammatory activity (Boots et al., 2008), high therapeutic potential for reducing blood pressure (Larson, Symons, \& Jalili, 2012), anti-cancer activity (Lamson \& Brignall, 2000) against prostate cancer (Sharmila, et al., 2014) and breast cancer (Deng, Song, Zhou, Yuan, \& Zheng, 2013), protection against Alzheimer's disease (Islam, Zaman, Jahan, \& Chakraborty, 2013), reduction of oxidative stress after intense exercise (Gao et al., 2014); reduction of muscle disorders in athletes (Askari et al., 2013). Furthermore, quercetin improves immunity, has an anti-aging effect, and acts against obesity, diabetes, and cardiovascular diseases.

\subsection{Curcumin}

Curcumin is a polyphenolic compound with the molecular formula of $\mathrm{C}_{21} \mathrm{H}_{20} \mathrm{O}_{6}$ containing $\alpha, \beta$-diketo group, carbon-carbon double bonds, and phenyl rings with various hydroxyl and methoxy groups. It exhibits keto enol tautomerism. It is major component of turmeric and soluble in lipids. It is a unique antioxidant with significant antioxidant activity and reported to be an excellent free radical scavenger. Antioxidant activity of curcumin related strongly with the phenolic $\mathrm{OH}$ group. Studies on structure-activity relationship(s) for the antioxidant effects of curcumin are controversial. Whereas few group researchers claimed that the strong activity of curcumin is because of the presence of hydroxyl moiety, some other researchers proposed the involvement of the carbonyl groups. Barclay et al., (2000) reported that curcumin could donate $\mathrm{H}$-atoms from the phenolic group (Barclay et al., 2000). In another study it was reported that curcumin is a strong $\mathrm{H}$ atom donor from the methylenic group rather than from the phenolic group (Jovanovic, Steenken, Boone, \& Simic, 1999). Priyadarsini et al., (2003) have also proposed that the phenolic group plays active role for the free-radical-scavenging activity indicating the increased activity by the methoxy group (Priyadarsini et al., 2003). Thus, curcumin features unique chain breaking antioxidant ability which is correlated to the phenolic $\mathrm{OH}$ group and $\mathrm{CH}_{2}$ group of the diketone moiety.

Curcumin is found in turmeric in significant amounts. Turmeric is one of the components of the curry spice mixture widely used in cooking. In Asian medicine, curcumin has been used for more than 4,000 years. It is non-toxic even at high doses. Consumption of up to $12 \mathrm{~g} / \mathrm{day}$ is well tolerated. Curcumin can be detected in blood serum in 1.5-2 hours after consumption of turmeric. One major problem with curcumin is its lower bioavailability. To address this problem several formulations with nanoparticles, liposomes, micelles, and phospholipid complexes have been prepared (Peng et al., 2014; pawar et al., 2012; Ghosh et al., 2012, Yallapu, Dobberpuhl, Maher, Jaggi, \& Chauhan, 2012; Gong et al., 2013; Pandelidou, Dima, Georgopoulos, Hatziantoniou, \& Demetzos, 2011). The recommended consumption level of curcumin is $100 \mathrm{mg} / \mathrm{day}$. Significant loss of spice ingredient was observed when the spices were subjected to heat treatments in cooking methods (Jayashree et al., 2016).

Curcumin's biological effects are summarized in several reports (Maheswari, Singh, Gaddipati, \& Srimal, 2006; Aggarwal, Surth, \& Shisodia, 2007; Goel, Kunnumakkara, \& Aggarawal, Kumar, \& Bharti, 2003). Curcumin is beneficial in cardiovascular diseases (Wu et al., 2004). It inhibits sclerosis (Coban et al., 2012) and reduces oxidation of low-density lipoproteins (Chen, 2006). It also neutralizes oxidative stress (Calaf et al., 2011) due to its strong antioxidative properties (Ak \& Gulcin, 2008). It has strong anticancer activity (Sarvjeet \& Ashok, 2006) against prostate cancer (Aggarwal, 2008) and melanoma. It is effective against Alzheimer's (Maheswari, Singh, Gaddipati, \& Srimal, 2006) and Parkinson's disease (Goel, Kunnumakkara, \& Aggarawal, 2008). In animal model oral administration of curcumin inhibited cancer in the colon, skin, stomach, liver, lung, duodenum, soft palate, and breasts of rodents (Rao, Rivenson, Simi, \& Reddy, 1995). Moreover, Curcumin improved impaired wound healing in diabetic mice.

\subsection{Resveratrol}

Resveratrol is one of the major nonflavonoids phenolic compounds where two aromatic rings are joined by an ethane linkage. Resveratrol exists in monomeric, oligomeric or polymeric form of stilbenes. It is a natural phytoalexin in the fruits and vegetables such as peanuts, mulberries, grapes, red cabbage, spinach, and red wine. The French paradox of wellness and wine consumption is attributed to the effect of resveratrol (Ferreiers, 2012; Renaud, de Lorgeril, 1992; Vidalayur, Otani, Singal, \& Maulik, 2006).

Resveratrol is currently receiving considerable attention worldwide because of its beneficial effects on the human health including significant antioxidant activity. Number of studies reported that resveratrol has strong antioxidant and radical scavenging capacity against DPPH, ABTS, DMPD, and superoxide radical and metal chelating activities. In the study Gülçin, (2010) found that compared to standard antioxidant resveratrol inhibited higher lipid peroxidation (89.1\%) of the lipid peroxidation of linoleic acid emulsion than BHA, BHT, 
$\alpha$-tocopherol, and trolox (approximately 80\%) at the concentration of $30 \mu \mathrm{g} / \mathrm{ml}$. (Gülçin, 2010)

Table 1. Food sources of strong natural antioxidants

\begin{tabular}{|c|c|c|c|}
\hline Antioxidant & Structural Formula & Food Sources & Analytical techniques \\
\hline $\begin{array}{l}\text { Epigallocatechin } \\
\text { gallate }\end{array}$ & & $\begin{array}{l}\text { Green tea, oolong tea, grapes, } \\
\text { wine, cocoa, \& dark chocolate }\end{array}$ & $\begin{array}{l}\text { RPHPLC, } \\
\text { LC-ESI-MS/MS, } \\
\text { spectroscopy, \& NMR }\end{array}$ \\
\hline Quercetin & & $\begin{array}{l}\text { Onion, apple, broccoli, kale, } \\
\text { apples, cranberries, bell peppers, } \\
\text { celery, tomatoes, \& apricocots }\end{array}$ & $\begin{array}{l}\text { RPHPLC, HPLC-PDA, } \\
\text { HPLC-UV, LC-MS/MS, Raman } \\
\text { Spectroscopy, \& } \quad \text { NMR } \\
\text { spectroscopy }\end{array}$ \\
\hline Curcumin & & Turmeric & $\begin{array}{l}\text { HPLC-UV, HPTLC, } \\
\text { Fluorescence UHPLC, UV-Vis } \\
\text { spectroscopy, LC-MS/MS, \& } \\
\text { UPLC-MS/MS }\end{array}$ \\
\hline Resveratrol & & $\begin{array}{l}\text { Japanese knotweed (Polygonum } \\
\text { cuspidatum), red grapes, red wine, } \\
\text { peanuts, mulberries, red cabbage, } \\
\text { \& spinach }\end{array}$ & $\begin{array}{l}\text { HPLC-UV, } \\
\text { HPLC-DAD, } \\
\text { LC-MS/MS, } \\
\text { RPHPLC, \& LC-DAD-FD-ED }\end{array}$ \\
\hline Hydroxytyrosol & $\mathrm{OH}$ & Olive, olive leaves, $\&$ olive oil & $\begin{array}{l}\text { HPLC-UV, RP-HPLC-DAD, } \\
\text { HPLC-MS, \& LC-MS/MS }\end{array}$ \\
\hline Astaxanthin & & $\begin{array}{l}\text { Algae, bacteria, fungi, yeast, } \\
\text { salmon, lobster, trout, krill, } \\
\text { shrimp, crayfish, red fish, \& red } \\
\text { fish roe }\end{array}$ & $\begin{array}{l}\text { UV-Vis, RP-HPLC, HPLC-MS, } \\
\text { LC-MS/MS, LC-APCI-MS, \& } \\
\text { LC-ESI-MS }\end{array}$ \\
\hline Lycopene & & $\begin{array}{l}\text { Tomatoes, watermelons, } \\
\text { wolfberry, } \\
\text { pink-grapefruits, apricots, } \\
\text { pink-guavas, red peppers, carrots, } \\
\text { olives, \& red grapefruit }\end{array}$ & $\begin{array}{l}\text { UV-Vis, RP-HPLC, } \\
\text { HPLC-MS/MS, \& LC-MS/MS, }\end{array}$ \\
\hline Dihydroquercetin & & $\begin{array}{l}\text { Citrus fruits, onion, bark of } \\
\text { Siberian larch, apples, larch, milk } \\
\text { thistle, tea, cocoa, \& vegetables }\end{array}$ & $\begin{array}{l}\text { UHPLC-MS/MS, HPLC-UV, \& } \\
\text { LC-MS/MS }\end{array}$ \\
\hline Lignans & $\mathrm{H}$ & $\begin{array}{l}\text { Flax seed, pumpkin seed, poppy } \\
\text { seed, sunflower seed, sesame } \\
\text { seed, nuts, berries, wheat, oat, rye, } \\
\text { coffee, tea, \& wine }\end{array}$ & $\begin{array}{l}\text { RPHPLC, HPLC-ESI-MS/MS, } \\
\text { LC-MS/MS, \& GC-MS }\end{array}$ \\
\hline
\end{tabular}

Cooking process such as roasting, boiling, and frying reduces the level of resveratrol. One of the big challenges for resveratrol is the low availability even after it is well absorbed and thus result in low plasma concentrations. In number of studies it was reported resveratrol as effective "therapeutic agent", however clinical and in vivo 
animal model studies indicated inconsistent results due to its low bioavailability showing sometime even $0 \%$ (Thazhath et al., 2016, De Vries, Strydom, Steenkamp, 2018). To enhance the bioavailability, better permeability and resistant to hydrolysis various formulation and alternative oral rout have been prepared (Watkins, Wu, Zhang, Davis, \& Xu, 2015, Ansari, Vavia, Trotta, \& Cavalli, 2011).

Biological activity of resveratrol was investigated in vitro and in vivo. It showed positive cardiovascular health, antioxidant activities, and prevention of platelet aggregation. It has also been reported that resveratrol has chemo preventive effectiveness against initiation, promotion, and progression of carcinogenesis. The anticancer activity of resveratrol has been shown in many studies (Yashin, Chernousova, Trukhanov, Chertushkin, \& Freidkina, 2001; Signorelli \& Gidoni, 2005; Whitlock \& Baek, 2012; Aggarwal et al., 2004) including its activity against breast cancer (Aggarwal et al., 2004), colon cancer (Wang, Li, \& Meng, 2012), and rectal cancer (Miki et al., 2012). Resveratrol inhibits Epstein-Barr virus (De Leo et al., 2012), herpes virus (Dochetry et al., 1999), and influenza virus (Mahady \& Pendland, 2000). Resveratrol was shown to inhibit cell proliferation in a dose-dependent manner. Resveratrol actively reduces the growth of Helicobacter pylori in the stomach. It showed an anti-aging and neuroprotective effect (Baur \& Sinclair, 2006; Aggarawal et al., 2004, Athar et al., 2007).

\subsection{Hydroxytyrosol}

Hydroxytyrosol is one of most potent natural antioxidant compounds with o-diphenols compounds under the group of phenolic alcohol compounds. Compared to the tyrosol, hydroxytrosol has one more $\mathrm{OH}$ group in the benzene ring and it contributes towards higher free radical scavenging and antioxidant activity. It is an amphipathic compound which has a water-soluble and fat-soluble component with alipophilic end and hydrophilic end. This unique structural feature makes hydroxytyrosol a good transporter of substances and penetrate the cellular membrane in human body (Fernández-Bolaños, López, López-García, \& Marset, 2012, Martínez, Ros, \& Nieto, 2018).

Hydroxytyrosol is present in olives and olive oil, as well as in other vegetable oils. It attributes intense flavor and aroma. Being reported hydroxytyrosol, tyrosol, and oleuropein as main polyphenolic antioxidants in olive oil, hydroxytyrosol has strongest antioxidant effects. Hydroxytyrosol is is fifteen and three times more antioxidant than green tea coenzyme Q10 respectively (Richards, 2012). The antioxidant properties of hydroxytyrosol has been explained based on various molecular, cellular and animal model studies. With respect to superoxide anion Visioli et al., (1998) proved that hydroxytyrosol has potent scavenging activity of superoxide formation (Visioli, Bellemo, \& Galli, 1998).

Virgin olive oil phenolic compounds are highly absorbed and showed bioavailability upto 70 to $99 \%$ depending on the age, hormonal status or gender of the patients. After ingestion they are absorbed in a dose-dependent manner. In a study with the administration of solution of hydroxytyrosol and tyrosol with olive and water Tuck et al., (2002) found higher bioavailability with olive oil compared to water (99\% and $98 \%$ respectively in olive oil solution, $75 \%$ and $71 \%$ in aqueous solution) (Tuck \& Hayball, 2002). Hydroxytyrosol is resistant to gastric juices and significantly bioavailable (Khymenets et al., 2016, Martínez, Ros, \& Nieto, 2018).

Hydroxytyrosol possesses several pharmacological activities, such as antioxidant, anticarcinogenic, anti-inflammatory, and neuroprotective activities (Hu, He, Jiang, \& Xu, 2014, Warleta, et al 2011, D'Angelo et al., 2005; Fabiani et al., 2002; Vazquez et al., 2010; Rodriguez Morato et al., 2015; Bulotta et al., 2014; Sun, Luo, \& Liu, 2014). It has an exceptionally beneficial effect on the cardiovascular system (Bullota et al., 2014). consumption of hydroxytyrosol in regular way help to reduce cardiovascular diseases and diabetes mellitus (Merola, Castillo, Benavente-Garcia, Ros, \& Nieto, 2017). Hydroxytyrosol is protective against neurodegenerative disorders Alzheimer or Parkinson's disease (Dexter \& Jenner, 2013). It possessed antimicrobial capacity by inhibiting the growth rate of bacteria as Escherichia coli, Candida albicans, Clostridium perfringens, Streptococcus mutans, or Salmonella enterica (Medina, De Castro, Romero, \& Brenes, 2006).

\subsection{Astaxanthin}

Astaxanthin is one of the strong natural carotenoid pigments and known as "the king of the carotenoids,". Astaxanthin is a member of the xanthophylls and consists of two terminal rings joined by a chain of conjugated double bonds. Astaxanthin occurs as stereoisomers, geometric isomers, free and esterified forms because of the presence of the polyene bonds. In this oxygenated derivative molecule, it has two rings with hydroxyl and keto moieties with two asymmetric carbons in both ends and exist in esterified (one or both) forms by reacting with a fatty acid, protein or lipoprotein (Ambati, Phang, \& Ravi, 2014). 
Astaxanthin are naturally available in genus algae, bacteria, fungi, yeast, salmon, lobster, trout, krill, shrimp, and crayfish. The astaxanthin content in common salmon products has been measured by the U.S. Food and Drug Administration that ranges from $5.4 \mathrm{mg} / \mathrm{kg}$ to $40.4 \mathrm{mg} / \mathrm{kg}$. Astaxanthin is also found in red fish roe. Another source of astaxanthin is a yeast, Phaffia, which grows on the bark of certain trees. Astaxanthin is found in its highest natural concentration in wild Pacific sockeye salmon in the range of $26-38 \mathrm{mg} / \mathrm{kg}$ flesh. Heat treatment reduce the level of astaxanthin while it is stable at $70-90{ }^{\circ} \mathrm{C}$. Improved storage condition at $4{ }^{\circ} \mathrm{C}$ and $25{ }^{\circ} \mathrm{C}$ were developed by mixing the astaxanthin with cyclodextrin-water mixture (Yuan, Du, Jin, \& Xu, 2013). Moreover lipid-based formulation of astaxanthin enhanced its bioavailability in human study (Olson, 2004).

Due to the unique structure of astaxanthin containing double bond, hydroxyl and keto group, it showed high antioxidant activity and even higher in comparison to other carotenoids such as lutein, lycopene, $\alpha$-carotene and $\beta$-carotene (Naguib, 2004). In another study it was found that antioxidant activity of astaxanthin was 10 times higher than carotenoids including zeaxanthin, lutein, canthaxanthin, $\beta$-carotene and compared to $\alpha$-tocopherol it was 100 times higher (Liu \& Osawa, 2007). Whereas the oxo groups in astaxanthin result in high antioxidant activities the polyene chain as well as the terminal ring in astaxanthin traps radicals and scavenge radical's activity (Martin, Jagger, Ruck, \& Schmidt, 1999). Astaxanthin protect the cell membrane from lipid peroxidation by scavenging the radicals at the outer and inner cell membranes (Ambati, Phang, \& Ravi, 2014). In a study Augusti et al., (2012) found the elevation of antioxidant enzymes activities of superoxide dismutase and thioredoxin reductase in serum when astaxanthin were fed to rabbits (Augusti et al., 2012). Similar observations were reported Kamath et al., (2008) when ethanol-induced gastric ulcer rats were treated with astaxanthin (Kamath, Srikanta, Dharmesh, Sarada, \& Ravisankar, 2008).

Many research studies have discussed the health benefits of astaxanthin (Higuera-Ciapara, Felix-Valenzuela, \& Goyoolea, 2006; Querin, Huntley, Olaizola, \& Haematococcus, 2003; Yang, Kim, \& Lee, 2013; Yuan et al., 2011). Major health benefits include therapeutic efficacy in people with cardiovascular diseases (Fasset \& Coombes, 2011), reduction of oxidative stress and inflammation processes, increase in immune function (Park et al., 2010), inhibition of cancer cell growth (Dore, 2005) specifically in neuroblastoma cancer (Ikeda et al., 2008), rectal cancer (Palloza et al., 2009), and skin cancer (Rao et al., 2013), protection from stomach ulcers (Murata et al., 2012), improvement of mental abilities (Katagiri, Satoh, Tsuji, \& Shirasawa, , 2012), beneficial in eye diseases (Iwasaki \& Tahara, 2006), protection of hepatic cells against damage (Curek et al., 2010), reduction of oxidative stress in overweight people (Choi et al., 2011), effect on insulin activity (Ishiki et al., 2013), and inhibition of oxidation of low-density lipoprotein (Iwamoto et al., 2000).

\subsection{Lycopene}

Lycopene is one of the major carotenoids among other 600 different carotenoids which could play crucial role in scavenging peroxyl radicals. It is an acylic isomer of beta carotene and contain a straight chain hydrocarbon with 11 conjugated and two non-conjugated double bonds. Due to the presence of these double bonds lycopene exist in cis-trans isomers.

Lycopene is found mainly in red fruits and vegetables such as tomatoes, watermelons, wolfberry, papaya, pink-grapefruits, apricots, pink-guavas, and peppers. In most of the natural resources it exists as trans isomerism. However, it can undergo cis-trans isomerisation with light heat and chemical reactions. Processing could significantly affect the bioavailability of lycopene by the trans to cis transformation. In a study it was found that lycopene from processed tomato juice in trans form is more bioavailable than raw tomato juice (Stahl \& Sies, 1992). In human plasma trans lycopene are more bioavailable than cis isomers (Clinton et al., 1996).

During lipid peroxidation peroxyl radical are generated and that could damage the lipids in the cell wall. Carotenoids play significant role in the protection from this damage of cellular membranes and lipoproteins by deactivating the peroxyl radicals via resonance stabilized radical adducts. Lycopene showed stronger singlet oxygen quenching ability compared beta carotene which is another most abundant carotenoids. Number of research studies have been published on the effects of lycopene on human health (Gerster, 1997; Agarawal \& Rao, 2000). Specific health benefits include beneficial in cardiovascular diseases (Gajendragadkar et al., 2014), reduction of the risk of heart attack (Ried \& Fakler, 2011) and atherosclerosis (Kohlmeier et al., 1997), reduction of blood pressure and serum cholesterol (Devaraj et al., 2008), effective suppression of oxidative stress (Devaraj et al., 2008; Kaur, Chauhan, \& Sandhir, 2011), anticancer activity (van Breeman \& Pajkovic, 2008; Omoni \& Aluko, 2005; Salman, Bergman, Djaldetti, \& Besler, 2007; Ford \& Erdman Jr, 2013; Seren et al., 2008), specifically, activity against prostate cancer (Giovannucci , 2002), rectal cancer (Tang et al., 2008), pancreatic cancer (Salman, Bergman, Djaldetti, \& Besler, 2007), breast cancer (Chalabi et al., 2006), and bladder cancer (Helzlsouer, Comstock, \& Morris, 1989), beneficial in the treatment of male infertility (Gupta \& Kumar, 2002), 
and beneficial in the treatment of Parkinson's disease (Kaur, Chauhan \&Sandhir, 2011).

\subsection{Dihydroquercetin}

Dihydroquercetin, also known as taxifolin is a flavanonol compounds which has two hydroxyl phenolic groups at the meta and para- positions in the phenyl rings in the flavonoid's skeleton.

Taxifolin is considered as antioxidant-rich functional food. It is highly available in citrus fruits and onion. Dihydroquercetin has a high antioxidant activity with approximately 60,000 ORAC units (Yashin et al., 2018; Pillow, et al., 1999). Due to its conjugation behavior and resonance structure stability of phenolic rings it provides powerful radical-scavenging activity. In a study Topal et al., (2016) found that taxifolin had remarkable radical scavenging with DMPD, ABTS, superoxide, and DPPH radicals, and metal chelating activities. It has been reported that scavenging activity of taxifolin against superoxide anion is more than that of BHA, BHT, $\alpha$-tocopherol, and Trolox (Topal et al., 2016).

Dihydroquercetin consumption has beneficial effects on human health such as: reduction in oxidative stress-related processes, specifically, in peroxide oxidation of cellular membrane lipids (Plotnikov, Aliev, Maslov, Vasileiv, \& Tjukavkina, 2003; Yashin et al., 2018; Kilkkinen et al., 2003), slowing down of premature aging, protective activity on capillaries, strengthening blood vessel walls (including capillaries), slowing cancer progression (Maikoparova, 2010; Moreno-Franco et al., 2011), normalization of blood cholesterol and triglycerides, which helps in atherosclerosis prevention (Plotnikov et al., 2004), reduction of risk for stroke and heart attack (Plotnikov, Aliev, Maslov, Vasileiv, \& Tjukavkina, 2003), prevention of dangerous diseases, such as cardiovascular diseases, cancer, and diabetes (Moreno-Franco et al., 2011), antidiabetic, antiallergic, diuretic, neuroprotective, and anti-inflammatory activities, positive effect on male and female reproductive system, reduction of chronic fatigue, improvement of mental and physical functions, and promoting burn wound healing (Teslekin, Zhambalova, Babenkova, Kelbanova \& Tukavina, 1996).

\subsection{Lignans}

Lignans are the group of phenolic compounds that is derived from the propylbenzene (C6-C3) unit.

Flaxseed (Linum usitatissimum L.) is a major source of of lignans. However other seeds, nuts, fruits, vegetables, coffee, tea, and wine also contain substantial amounts of lignans. Secoisolariciresinol diglucoside (SDG) is the major lignan present in flaxseed and it exist as component of a linear ester-linked complex. It has been observed that SDG is converted into enterolactone (ED) and enterodiol (EL) after its metabolism via the formation of secoisolariciresinol (SECO), a plant aglycon formed by the hydrolysis of SDG.

Flaxseed lignan secoisolariciresinoldiglucoside (SDG) and mammalian lignans enterodiol (ED) and enterolactone (EL) have been reported to play important role in protection from DNA damage and lipid peroxidation. In a study $\mathrm{Hu}$ et al., (2007) found that efficacy of lignans with the order of SDG > $\mathrm{SECO}>>\mathrm{ED}>\mathrm{EL}$ for DNA damage and SDG $>\mathrm{SECO}=\mathrm{ED}=\mathrm{EL}$ for liposome lipid peroxidation $(\mathrm{Hu}, \mathrm{He}, \mathrm{Jiang}, \&$ $\mathrm{Xu}, 2007)$. Strong antioxidant activity of SDG and SECO were observed due to the presence of 3-methoxy-4-hydroxyl substituents in SDG while the mammalian lignan had only single hydroxyl group. The strong antioxidant activity of the mammalian lignans in an aqueous environment were appeared due to the ability of the benzylic hydrogen abstraction and resonance stabilized phenoxyl radicals.

In vitro and in vivo studies demonstrated that flaxseed lignan and its mammalian metabolites showed protective effects against several chronic diseases. (Yuan et al., 1999; Prasad, 2009; Thompson, Boucher, Liu, Cotterchio, \& Kreiger, 2003). Interest towards lignans has been growing in recent years because of its significant antioxidant properties (Willfor et al., 2003; Yashin et al., 2017) and positive effects on human health (Adlercreutz, 2007), particularly, on cardiovascular diseases (Prasad, 2009; Maslov et al., 2016). It reduced the risk of cancer (Adlercreutz et al., 1992; Zhukova et al., 2010; Webb, \& McCullough, 2005; Zhukova et al., 2010; Pojer, Mattivi, Jhonson \&Stockley, 2013), especially hormone-dependent types, breast and ovarian cancer in women and prostate cancer in men. Recently, the ability of lignans to exhibit neural cell activity and stimulate neural cell repairing were also shown (Lores, Yashunsky, Nifantiev, \& Schachner, 2014).

\section{Conclusion}

The review describes an overview of selected most powerful natural antioxidant compounds with their structure, source, bioavailability, antioxidant properties, and key healthcare effects. In addition to these selected antioxidant compounds several other antioxidant compounds have been reported with significant antioxidant activity such as phenolic acids in coffee and berries and anthocyanins in berries and fruits, isoflavones in soy, and proanthocyanidins in cranberries. From the recent studies on the powerful antioxidant compounds it was found that antioxidant activity of a natural antioxidant depends on the number of hydroxyl group in the 
phenylring of the phenolic compounds as well as carbon carbon bonds in aliphatic skeleton. For few decades, efforts have been made by researchers to fill the knowledge gap between consumers and food nutrition in search for healthy diet. Information on such natural oxidants is expected to insight valuable source since current dietary guidelines recommend increasing the antioxidant rich foods. Despite the evidence of efficacy and safety of antioxidant compounds it has been found that most of the antioxidant compounds possessed limited bioavailability. Further studies to improve the bioavailability and medicinal value are needed for potential application.

\section{References}

Adak, M., \& Gabar, M. A. (2011). Green tea as a functional food for better health: A brief review. Research Journal of Pharmaceutical, Biological and Chemical Sciences, 2, 645-664.

Adlercreutz, H. (2007). Lignans and human health. Critical Reviews in Clinical Laboratory Science, 44, 483-525. https://doi.org/10.1080/10408360701612942

Adlercreutz, H., Mousavi, Y., Clark, J., Hockerstedt, K., Hamalainen, E., Wahala, K., Makela, T., \& Hase, T. (1992). Dietary phytoestrogens and cancer: in vitro and in vivo studies. The Journal of Steroid Biochemistry and Molecular Biology, 41, 331-337. https://doi.org/10.1016/0960-0760(92)90359-Q

Aggarwal, B. B., Kumar, A., \& Bharti, A. C. (2003). Anticancer potential of curcumin: preclinical and clinical studies. Anticancer Research, 23, 363-398.

Aggarwal, B. B. (2008). Prostate cancer and curcumin: add spice to your life. Cancer Biology and Therapy, 7(9), 1436-1440. https://doi.org/10.4161/cbt.7.9.6659

Aggarwal, B. B., Bhardwaj, A., Aggarwal, R. S., Seeram, N. P., Shisodia, S., \& Takada, Y. (2004). Role of resveratrol in prevention and therapy of cancer: preclinical and clinical studies. Anticancer Research, 24, 2783-2840.

Agarwal, S., \& Rao, A. V. (2000). Tomato lycopene and its role in human health and chronic diseases. Canadian. Association Journal, 163(6), 739-744.

Aggarwal, B. B., Surth, Y. H., \& Shishodia, S. (2007). The molecular targets and therapeutics of curcumin in health and disease. Advances in Experimental Biology, 77-172. https://doi.org/10.1007/978-0-387-46401-5

Ak, T., \& Gulcin, I. (2008). Antioxidant and radical scavenging properties of curcumin. Chemico-Biological Interactions, 174(1), 27-37. https://doi.org/10.1016/j.cbi.2008.05.003

Amri A., Chaumeil J. C., Sfar S., \& Charrueau C. (2012). Administration of resveratrol: What formulation solutions to bioavailability limitations? Journal of Controlled Release, 158, 182-193. 10.1016/j.jconrel.2011.09.083

Ambati R. R., Phang S. M., Ravi S., \& Aswathanarayana R. G. (2014). Astaxanthin: sources, extraction, stability, biological activities and its commercial applications - a review. Marine Drugs, 12, 128-152. https://doi.org/10.3390/md12010128

Ansari, K. A., Vavia, P. R., Trotta, F., \& Cavalli, R., (2011). Cyclodextrin-based nanosponges for delivery of resveratrol: in vitro characterisation, stability, cytotoxicity and permeation study. American Association of Pharmaceutical Society Pharmaceutical Science and Technology, 12, 279-286. https://doi.org/10.1208/s12249-011-9584-3

Arab, L., \& Il'yasova, D. (2003). The epidemiology of tea consumption and colorectal cancer. Journal of Nutrition, 133, 3310S-3318S. https://doi.org/10.1093/jn/133.10.3310S

Arab, L., Liu, W., \& Elashoff, D. (2009). Green and black tea consumption and risk of stroke: A meta-analysis. Stroke, 40, 1786-1792. https://doi.org/10.1161/STROKEAHA.108.538470

Askari, G., Ghiasvand, R., Paknahad, Z., Karimian, J., Rabiee, K., Sharifirad, G., \& Feizi, A. (2013). The effects of quercetin supplementation on body composition, exercise performance and muscle damage indices in athletes. International Journal of Preventive Medicine, 4, 21-26.

Athar, M., Back J. H., Tang, X., Kim, K. H., Kopelovich L., Bickers, D. R., \& Kim A. L. (2007). Resveratrol: a review of preclinical studies for human cancer prevention. Toxicology and Applied Pharmacology, 224, 274-283. https://doi.org/10.1016/j.taap.2006.12.025

Augusti, P. R., Quatrin, A., Somacal, S., Conterato, G. M., Sobieskim, R., Ruviaro, A. R., Maurer, L.H., Duarte, M. M., Roehrs, M., \& Emanuelli, T. (2012). Astaxanthin prevents changes in the activities of thioredoxin 
reductase and paraoxonase in hypercholesterolemic rabbits. Journal of Clinical Biochemistry and Nutrition, 51, 42-49. https://doi.org/10.3164/jcbn.11-74

Baba, Y., Sonoda, J., Hayashi, S., Tosuji, N., Sonoda, S., Makisumi, K., \& Nakajo, M. (2012). Reduction of oxidative stress in liver cancer patients by oral green tea polyphenol tablets during hepatic arterial infusion chemotherapy. Experimental and Therapeutic Medicine, 4, 452-458. https://doi.org/10.3892/etm.2012.602

Balentine, D. A., \& Paetau-Robinson, I. Tea as a source of dietary antioxidants with a potential role in prevention of chronic diseases. In Herbs, B., \& Teas, M. G., \& Oomah, B. D. (Eds.), Technomic Publishing Co., Inc.: Lancaster, USA, 2000, pp. 265-287.

Barclay, L. R. C., Vinqvist,M. R., Mukai, K., Goto, H., Hashimoto, Y., Tokuanga, A., \& Uno, H. (2000). The antioxidant mechanism of curcumin: Classical methods are needed to determine antioxidant mechanism and activity. Organic Letter, 2, 2841-2843. https://doi.org/10.1021/ol000173t

Baur, J. A., \& Sinclair, D. A. (2006). Therapeutic potential of resveratrol: the in vivo evidence. Nature Reviews Drug Discovery, 5, 493-506. https://doi.org/10.1038/nrd2060

Beecher, G. R. (1999). Antioxidant Food Supplements in Human Health, Flavonoids in Foods.

Boots A. W., Kubben, N., Haenen, G. R. M. M., \& Bast, A. (2003). Oxidized quercetin reacts with thiols rather than with ascorbate: Implication for quercetin supplementation. Biochemical Biophysical Research Communication, 308, 560- 565. https://doi.org/10.1016/S0006-291X(03)01438-4

Boots, A. W., Wilms, L. C., Swennen, E. L., Kleinjans, J. C., Bast, A., \& Haenen, G. R. (2008). In vitro and ex vivo anti-inflammatory activity of quercetin in healthy volunteers. Nutrition, $24,703-710$. https://doi.org/10.1016/j.nut.2008.03.023

Borrelli, F., Capasso, R., Russo, A., \& Ernst, E. (2004). Systematic review: green tea and gastrointestinal cancer risk. Alimentary Pharmacology and Therapeutics, 19, 497-510.

Bors, W., Heller, W., Michel, C., \& Saran, M. (1990). Radical chemistry of flavonoid antioxidants. In: Emerit, I.; Packer, L.; Auclair, C. (Eds.) Antioxidants in Therapy and Preventive Medicine. Advances in Experimental Medicine and Biology. Plenum Press. 264, New York, p. 165-170.

Brausi, M., Rizzi, F., \& Bettuzzi, S. (2008). Chemoprevention of human prostate cancer by green tea catechins: two years later. A follow-up update. European Urology, 54, 472-473. https://doi.org/10.1016/j.eururo.2008.03.100

Brown, J. E., \& Kelly, M. F. (2007). Inhibition of lipid peroxidation by anthocyanin, anthocyanidins and their phenolic degradation products. European Journal of Lipid Science and Technology, 109, 66-71. https://doi.org/10.1002/ejlt.200600166

Brewer M. S. (2011). Natural antioxidants: sources, compounds, mechanism of action, and potential applications. Comprehensive Reviews in Food Science and Food Safety, 10, 221-247. https://doi.org/10.1111/j.1541-4337.2011.00156.x

Butler, L. M., Huang, J. Y., Wang, R., Lee, M. J., Yang, C. S., Gao, Y. T., \& Yuan, J. M. (2015). Urinary biomarkers of catechins and risk of hepatocellular carcinoma in the shanghai cohort study. American Journal of Epidemiology, 181, 397-405. https://doi.org/10.1093/aje/kwu304

Bulotta, S., Celano, M., Lepore, S. M., Montalcini, T., Pujia, A., \& Diego, R. (2014). Beneficial effects of the olive oil phenolic components oleuropein and hydroxytyrosol: focus on protection against cardiovascular and metabolic diseases. Journal of Translational Medicine, 12, 219. https://doi.org/10.1186/s12967-014-0219-9

Carvalho, M., Jerónimo, C., Valentão, P., Andrade, P. B., \& Silva, B. M. (2010). Green tea: A promising anticancer agent for renal cell carcinoma. Food Chemistry, 122, 49-54. https://doi.org/10.1016/j.foodchem.2010.02.014

Calaf, G. M., Echiburú-Chau, C., Roy, D., Chai, Y., Wen, G., \& Balajee, A. S. (2011). Protective role of curcumin in oxidative stress of breast cells. Oncology Reports, 26, 1029-1035. https://doi.org/10.18632/oncotarget.25323

Camouse, M. M., Domingo, D. S., Swain, F. R., Conrad, E. P., Matsui, M. S., Maes, D., Declercq, L., Cooper, K. D., Stevens, S. R., \& Baron, E. D. (2009). Topical application of green and white tea extracts provides protection from solar-simulated ultraviolet light in human skin. Experimental Dermatology, 18, 522-526. https://doi.org/10.1111/j.1600-0625.2008.00818.x 
Chalabi, N., Delort, L., Le Corre, L., Satih, S., Bignon, Y. J., \& Bernard-Gallon, D. (2006). Gene signature of breast cancer cell lines treated with lycopene. Pharmacogenomics, 7(5), 663-672. https://doi.org/10.2217/14622416.7.5.663

Chatterjee, P., Chandra, S., Dey, P., \& Bhattacharya, S. (2012). Evaluation of anti-inflammatory effects of green tea and black tea: a comparative in vitro study. Journal of Advanced Pharmaceutical Technology and Research, 3(2), 136-138. https://doi.org/10.4103/2231-4040.97298

Chen, W. F. (2006). Curcumin and its analogues as potent inhibitors of low-density lipoprotein oxidation. Free Radical Biology and Medicine, 40(3), 526-535. https://doi.org/10.1016/j.freeradbiomed.2005.09.008

Chen, X, McClements, D. J., Zhu, Y., Chen, Y., Zou, L., Liu, W., Cheng, C., Fu, D., \& Liu, C. (2018). Enhancement of the solubility, stability and bioaccessibility of quercetin using protein-based excipient emulsions. Food Research International, 114, 30-37. https://doi.org/10.1016/j.foodres.2018.07.062

Choi, H. D., Kim, J. H., Chang, M. J., Kyu-Youn, Y., \& Shin W. G. (2011). Effects of astaxanthin on oxidative stress in overweight and obese adults. Phytotherapapy Research, 25, 1813-1818. https://doi.org/10.1002/ptr.3494

Chu, Y. F. (2012). Coffee: Emerging Health Effects and Disease Prevention; Wiley-Blackwell: Ames, USA.

Clinton S. K., Emenhiser, C., Schwartz, S.J., Bostwick, D. G., Williams, A. W., Moore, B. J., \& Erdman, J. W. (1996). Cis-trans lycopene isomers, carotenoids and retinol in the human prostate. Cancer Epidemiology, Biomarkers \& Prevention, 5, 823-833.

Coban, D., Milenkovic, D., Chanet, A., Khallou, J. L., Sabbe, L., Palagani, A., Vanden, W. B., Mazur, A., \& Morand, C. (2012). Dietary curcumin inhibits atherosclerosis by affecting the expression of genes involved in leukocyte adhesion and transendothelial migration. Molecular Nutrition and Food Research, 56(8), 1270-1281. https://doi.org/10.1002/mnfr.201100818

Curek, G. D., Cort, A., Yucel, G. Demir, N., Ozturk, S., Elpek, G. O., Savas, B., \& Aslan, M. (2010). Effect of astaxanthin on hepatocellular injury following ischemia/reperfusion. Toxicology, 267, 147-153. https://doi.org/10.1016/j.tox.2009.11.003

D'Angelo, S., Ingrosso, D., Migliardi, V., Sorrentino, A., Donnarumma, G., Baroni, A., Masella, L., Antonietta Tufano, M., Zappia, M., \& Galletti, P. (2005). Hydroxytyrosol, a natural antioxidant from olive oil, prevents protein damage induced by long-wave ultraviolet radiation in melanoma cells. Free Radical Biology and Medicine 38, 908-919. https://doi.org/10.1016/j.freeradbiomed.2004.12.015

De Leo, A., Arena, G., Lacanna, E. Oliviero, G., Colavita, F., \& Mattia, E. (2012). Resveratrol inhibits Epstein Barr virus lytic cycle in Burkitt's lymphoma cells by affecting multiple molecular targets. Antiviral Research, 96(2), 196-202. https://doi.org/10.1016/j.antiviral.2012.09.003

De Vries, K., Strydom, M., \& Steenkamp, V. (2018). Bioavailability of resveratrol: possibilities for enhancement, Journal of Herbal Medicine, 11, 71-77. https://doi.org/10.1016/j.hermed.2017.09.002

Deng, X. H., Song, H. Y., Zhou, Y. F., Yuan, G. Y., \& Zheng, F. J. (2013). Effects of quercetin on the proliferation of breast cancer cells and expression of surviving in vitro. Experimental and Therapeutic Medicine, 6, 1155-1158. https://doi.org/10.3892/etm.2013.1285

Devaraj, S. Mathur, S., Basu, A., Aung, H. H., Vasu, V. T., Meyers, S., \& Jialal, I. (2008). A dose-response study on the effects of purified lycopene supplementation on biomarkers of oxidative stress. Journal of American of College Nutrition, 27(2), 267-273.

Dexter, D. T., \& Jenner, P. (2013). Parkinson disease: from pathology to molecular disease mechanisms. Free Radical Biology and Medicine, 62, 132-144. https://doi.org/10.1016/j.freeradbiomed.2013.01.018

Docherty, J. J., Fu, M. M., Stiffler, B. S., Limperos, R. J., Pokabla, C. M., \& DeLucia, A. L. (1999). Resveratrol inhibition of herpes simplex virus replication. Antiviral Research, 43, 145-155. https://doi.org/10.1016/S0166-3542(99)00042-X

Dore, J. E. (2005). Astaxanthin and cancer chemoprevention. In Bagchi, D., \& Preuss, H. G. (Eds.), Phytopharmaceuticals in Cancer Chemoprevention (pp. 555-570). CRC Press: Boca Raton, USA.

Dragicevic, N., Smith, A., Lin, X., Yuan, F., Copes, N., Delic, V., Tan, J., Cao, C., Shytle, R. D., \& Bradshaw, P. C. (2011). Green tea epigallocatechin-3-gallate (EGCG) and other flavonoids reduce Alzheimer's amyloidinduced mitochondrial dysfunction. Journal of Alzheimers Disease, 26, 507-21.

https://doi.org/10.3233/JAD-2011-101629 
Fabiani, R., De Bartolomeo, A., Rosignoli, P., Servili, M., Montedoro, G. F., \& Morozzi, G. (2002). Cancer chemoprevention by hydroxytyrosol isolated from virgin olive oil through G1 cell cycle arrest and apoptosis. European Journal of Cancer Prevention, 11(4), 351-358.

Fassett, R. G., \& Coombes, J. S. (2011). Astaxanthin: a potential therapeutic agent in cardiovascular disease. Marine Drugs, 9, 447-465. https://doi.org/10.3390/md9030447

Fernández-Bolaños, J. G., López, O., López-García, M. A., \& Marset, A. (2012). Biological properties of Hydroxytyrosol and its derivates. In Olive Oil-Constituents, Quality, Health Properties and Bioconversions; In Tech: London, UK, pp. 375-398.

Ferrieres, J. (2012). The French paradox: lessons for other countries. Heart, 90(107), 111.

Ford, N., \& Erdman, J. W. (2013). Lycopene and cancer. In Carotenoids and Human Health. Springer: New York, USA, pp. 193-214.

Gajendragadkar, P. R., Hubsch, A., Mäki-Petäjä, K. M., Serg, M., Wilkinson, I. B., \& Cheriyan, J. (2014). Effects of oral lycopene supplementation on vascular function in patients with cardiovascular disease and healthy volunteers: a randomised controlled trial. PLoS One, 9(6), e99070.

https://doi.org/10.1371/journal.pone.0099070

Gao, C., Chen, X., Li, J., Li. Y., Tang, Y., Liu, L., Chen, S., Yu, H., Liu, L., \& Yao, P. (2014). Myocardial mitochondrial oxidative stress and dysfunction in intense exercise: regulatory effects of quercetin. European Journal of Applied Physiology, 114, 695-705. https://doi.org/10.1007/s00421-013-2802-9

Gerster, H. (1997). The potential role of lycopene for human health. The Journal of American College of Nutrition, 16(2), 109-126.

Ghosh, D., Choudhury, S. T., Ghosh, S., Mandal, A. K., Sarkar, S., Ghosh, A., Saha, K. D., \& Das, N. (2012). Nanocapsulated curcumin: oral chemopreventive formulation against diethylnitrosamine induced hepatocellular carcinoma in rat. Chemical Biology Interaction, 195, 206-214. https://doi.org/10.1016/j.cbi.2011.12.004

Giovannucci, E. (2002). A review of epidemiologic studies of tomatoes, lycopene, and prostate cancer. Experimental Biology and Medicine (Maywood), 227(10), 852-859.

Goel, A., Kunnumakkara, A. B., \& Aggarwal, B. B. (2008). Curcumin as Curecumin: from kitchen to clinic. Biochemical Pharmacology, 75, 787-809. https://doi.org/10.1016/j.bcp.2007.08.016

Gong, C., Deng, S., Wu, Q., Xiang, M., Wei, X., Li, L., Gao, X., Wang, B., Sun, L., Chen, Y., Li,Y., Liu, L., Qian, Z., \& Wei, Y. (2013). Improving antiangiogenesis and anti-tumor activity of curcumin by biodegradable polymeric micelles. Biomaterials, 34, 1413-32. https://doi.org/10.1016/j.biomaterials.2012.10.068

Grassi, D., Desideri, G., Di Giosia, P., Feo, M. D., Fellini, E., Cheli, P., Ferri, L., \& Ferri, C. (2013). Tea, flavonoids, and cardiovascular health: endothelial protection. American Journal of Clinical Nutrition, 98(Suppl. 6), 1660S-1666S. https://doi.org/10.3945/ajcn.113.058313

Grzesik, M., Naparło, K., Bartosz, G., \& Sadowska-Bartosz, I. (2018). Antioxidant properties of catechins: comparison with other antioxidants. Food Chemistry, 241, 480-492. https://doi.org/10.1016/j.foodchem.2017.08.117

Gupta, N. P., \& Kumar, R. (2002). Lycopene therapy in idiopathic male infertility-a preliminary report. International Urology and Nephrology, 34(3), 369-372.

Gülçin, İ. (2010). Antioxidant properties of resveratrol: A structure-activity insight. Innovative Food Science and Emerging Technologies, 11, 210-218. https://doi.org/10.1016/j.ifset.2009.07.002

Hodgson, J. M. (2008). Tea flavonoids and cardiovascular disease. Asia Pacific Journal of Clinical Nutrition, 17(S1), 288-290.

Halvorsen, B. L, Carlsen, M. H., Phillips, K. M., Holte, K., Jacobs, D. R., \& Blomhoff, R. (2006) Content of redox active compounds (ie, antioxidnats) in foods consumed in the United States. American Journal of Nutrition, 84, 95-135. https://doi.org/10.1093/ajcn/84.1.95

Hayat, K., Iqbal, H., Malik, U., Bilal, U., \& Mushtag, S. (2015). Tea and its consumption: benefits and risks. Critical Reviews on Food Science and Nutrition, 53, 939-954. https://doi.org/10.1080/10408398.2012.678949

He, J., Xu, L., Yang, L., \& Wang, X. (2018). Epigallocatechin gallate is the most effective catechin against 
antioxidant stress via hydrogen peroxide and radical scavenging activity. Medical Science Monitor, 14, 8198-8206. https://doi.org/10.12659/MSM.911175.

Helzlsouer, K. J., Comstock, G. W., \& Morris, J. S. (1989). Selenium, lycopene, alpha-tocopherol, beta-carotene, retinol, and subsequent bladder cancer. Cancer Research, 49(21), 6144-6148.

Higuera-Ciapara, I., Felix-Valenzuela, L., \& Goyoolea, F. M. (2006). Astaxanthin: a review of its chemistry and applications. Critical Reviews in Food Science and Nutrition, 40, 185-196. https://doi.org/10.1080/10408690590957188

Hu, T., He, X. W., Jiang, J. G., \& Xu, X. L. (2014). Hydroxytyrosol and its potential therapeutic effects. Journal of Agricultural and Food Chemistry, 62, 1449-1455. https://doi.org/10.1021/jf405820v

Islam, M. R., Zaman, A., Jahan, I., Chakravorty, R., \& Chakraborty, S. (2013). In silico QSAR analysis of quercetin reveals its potential as therapeutic drug for Alzheimer's disease. Journal of Young Pharmacists, 5, 173-179. https://doi.org/10.1016/j.jyp.2013.11.005

Ide, K., Yamada, H., Takuma, N., Park, M., Wakamiya, N., Nakase, J., Ukawa, Y., \& Sagesaka, Y. M. (2014). Green tea consumption affects cognitive dysfunction in the elderly: a pilot study. Nutrients, 6(10), 4032-42. https://doi.org/10.3390/nu6104032

Ikeda, Y., Tsuji, S., Satoh, A., Satoh, A., Ishikura, M., Shirasawa, T., \& Shimizu, T. (2008). Protective effects of astaxanthin on 6-hydroxydopamine-induced apoptosis in human neuroblastoma SH-SY5Y cells. Journal of Neurochemistry, 107, 1730-1740. https://doi.org/10.1111/j.1471-4159.2008.05743.x

Ikeda, I., Tsuda, K., Suzuki, Y., Kobayashi, M., Unno, T., Tomoyori, H., Goto, H., Kawata, Y., Imaizumi, K., Nozawa, A., \& Kakuda, T. (2005). "Tea catechins with a galloyl moiety suppress postprandial hypertriacylglycerolemia by delaying lymphatic transport of dietary fat in rats," The Journal of Nutrition, 135(2), 155-159. https://doi.org/10.1093/jn/135.2.155

Ioku, K., Aoyama, Y., Tokuno, A., Terao, J., Nakatani, N., \& Takei, Y. (2001). Various cooking methods and the flavonoid content in onion. Journal of Nutrional Science and Vitaminology, 147(1), 78-83.

Ishiki, M., Nishida, Y., Ishibashi, H., Wada, T., Fujisaka, S., Takikawa, A., Urakaze, M., Sasaoka, T., Usui, I., \& Tobe, K. (2013). Impact of divergent effects of astaxanthin on insulin signaling in L6 cells. Endocrinology, 154, 2600-2612. https://doi.org/10.1210/en.2012-2198

Iwasaki, T., \& Tahara, A. (2006). Effects of astaxanthin on eyestrain by accommodative dysfunction. Journal of Eye, 23, 829-834.

Iwamoto, T., Hosoda, K., Hirano, R., Kurata, H., Matsumoto, A., Miki, W., Kamiyama, M., Itakura, H., Yamoto, S., \& Kondo, K. (2000). Inhibition of low-density lipoprotein oxidation by astaxanthin. Journal of Atherosclerosis Thrombosis, 7, 216-222.

Jayashree, E., \& Zachariah, T. J. (2016). Processing of turmeric (Curcuma longa) by different curing methods and its effect on quality. Indian Journal of Agricultural Sciences, 86, 696-698.

Jovanovic S. V., Steenken S., Boone, C. W., \& Simic M. G. (1999). H-atom transfer is a preferred antioxidant mechanism of curcumin. Journal of American Chemical Society, 121, 9677-9681. https://doi.org/10.1021/ja003823x

Juneja, L. R., Kapoor, M. P., Okubo, T., \& Rao, T. (2013). Green Tea Polyphenols: Nutraceuticals of Modern Life; CRC Press: Boca Raton, USA.

Kajimoto, O., Kajimoto, Y., \& Kakuda, T. (2003). Tea catechins reduce serum cholesterol levels in mild and borderline hypercholesterolemia patients. Journal of Clinical Biochemistry and Nutrition, 33, 101-111.

Kamath, B. S., Srikanta, B. M., Dharmesh, S. M., Sarada, R., \& Ravishankar, G. A. (2008). Ulcer preventive and antioxidative properties of astaxanthin from Haematococcus pluvialis. European Journal of Pharmacology, 590, 387-395. https://doi.org/10.1016/j.ejphar.2008.06.042

Katiyar, S., Elmets, C. A., \& Katiyar, S. K. (2007). Green tea and skin cancer: photoimmunology, angiogenesis and DNA repair. Journal of Nutritional Biochemistry, 18, 287-296. https://doi.org/10.1016/j.jnutbio.2006.08.004

Katagiri, M., Satoh, A., Tsuji, S., \& Shirasawa, T. (2012). Effects of astaxanthin rich Haematococcus pluvialis extract on cognitive function: a randomised, double-blind, placebo-controlled study. Journal of Clinical Biochemistry and Nutrition, 51, 102-107. https://doi.org/10.3164/jcbn.D-11-00017 
Kaur, H., Chauhan, S., \& Sandhir, R. (2011). Protective effect of lycopene on oxidative stress and cognitive decline in rotenone induced model of Parkinson's disease. Neurochemical Research, 36(8), 1435-1443. https://doi.org/10.1007/s11064-011-0469-3

Keske, M. A., Ng, H. L., Premilovac, D., Rattigan, S., Kim, J. A., Munir, K., Yang, P., \& Quon, M. J. (2015). Vascular and metabolic actions of the green tea polyphenol epigallocatechin gallate. Current Medicinal Chemistry, 22, 59-69.

Khymenets, O., Crespo, M. C., Dangles, O., Rakotomanomana, N., Andres-Lacueva, C., \& Visioli, F. (2016). Human hydroxytyrosol's absorption and excretion from a nutraceutical. Journal of Functional Foods, 23, 278-282. https://doi.org/10.1016/j.jiff.2016.02.046

Kilkkinen, A., Valsta, L. M., Virtamo, J., Stumpf, K., Adlercreutz, H., \& Pietinen, P. (2003). Intake of lignans is associated with serum enterolactone concentration in Finnish men and women. Journal of Nutrition, 133, 1830-1833. https://doi.org/10.1093/jn/133.6.1830

Klein, K. (Ed.). (2014). Antioxidants in Food, Vitamins and Supplements. Elsevier: San Diego, USA.

Kushiyama, M., Shimazaki, Y., Murakami, M., \& Yamashita, Y. (2009). Relationship between intake of green tea and periodontal disease. Journal of Peridontology, 80, 372-377. https://doi.org/10.1902/jop.2009.080510

Kohlmeier, L., Kark, J. D., Gomez-Gracia, E., Martin, B. C., Steck, S. E., Kardinaal, A. F., Ringstad, J., Thamm, M., Masaev, V., Riemersma, R., Martin-Moeno, J. M., Huttunen, J. K., \& Kok, F. J. (1997). Lycopene and myocardial infarction risk in the EURAMIC Study. American Journal of Epidemiology, 146(8), 618-626. https://doi.org/10.1093/oxfordjournals.aje.a009327

Kumar, A., Ahuja, A., Ali, J., \& Baboota, S. (2012). Curcumin loaded nano globules for solubility enhancement: preparation, characterization and ex vivo release study. Journal of Nanoscience and Nanotechnology, 12, 8293-302.

Lamson, D. W., \& Brignall, M. S. (2000). Antioxidants and cancer, part 3: quercetin. Alternative Medicine Review, 5, 196-208.

Larson, A. J., Symons, J. D., \& Jalili, T. (2012). Therapeutic potential of quercetin to decrease blood pressure: review of efficacy and mechanisms. Advances in Nutrition, 3, 39-46. https://doi.org/10.3945/an.111.001271.

Lin, Y. T., Wu, Y. H., Tseng, C. K., Lin, C. K., Chen, W. C., Hsu, Y. C., \& Lee, J. C. (2013). Green tea epicatechins inhibit hepatitis $\mathrm{C}$ virus replication via cycloxygenase-2 and attenuate virus-induced inflammation. PloS One, 8(1), e54466. https://doi.org/10.1371/journal.pone.0054466.

Li, Q., Kakizaki, M., Kuriyama, S., Sone, T., Yan, H., Nakaya, N., Mastuda-Ohmori, K., \& Tsuji, I. (2008). Green tea consumption and lung cancer risk: The Ohsaki study. British Journal of Cancer, 99, 1179-1184. https://doi.org/10.1038/sj.bjc.6604645

Li, M. J., Yin, Y. C., Wang, J., \& Jiang, Y. F. (2014). Green tea compounds in breast cancer prevention and treatment. World Journal of Clinical Oncology, 5, 520-528. https://doi.org/10.5306/wjco.v5.i3.520

Liu, G., Mi, X. N., Zheng, X. X., Xu, Y. L., Lu, J., \& Huang, X. H. (2014). Effects of tea intake on blood pressure: a meta-analysis of randomised controlled trials. British Journal Nutrition, 112, 1043-1054. https://doi.org/10.1017/S0007114514001731

Liu, S., Li, H., Chen, L., Yang, L., Li, L., Tao, Y., Li, W., Li, Z., Liu, H., Tang, M., Bode, A. M., Dong, Z., \& Xao, Y. (2013). (-)-Epigallocatechin-3-gallate inhibition of Epstein-Barr virus spontaneous lytic cycle infection involves ERK1/2 and PI3-K/Akt signaling in EBV-positive cells. Carcinogenesis, 34(3), 627-637.

Liu, X., \& Osawa, T. (2007). Cis astaxanthin and especially 9-cis astaxanthin exhibits a higher antioxidant activity in vitro compared to the all trans isomer. Biochemical and Biophysical Research Communication, 357, 187-193. https://doi.org/10.1016/j.bbrc.2007.03.120

Loers, G., Yashunsky, D. V., Nifantiev, N. E., \& Schachner, M. (2014). Neural cell activation by phenolic compounds from the Siberian Larch (Larix sibirica). Journal of Natural Products, 77(7), 1554-1561. https://doi.org/10.1021/np4009738

Maheshwari, R. K., Singh, A. K., Gaddipati, J., \& Srimal, R. C. (2006). Multiple biological activities of curcumin: a short review. Life Science, 78, 2081-2087.

Ma, J. J., Yu Y. G., Yin, S. W., Tang, C. H., \& Yang, X. Q. (2018). Cellular uptake and intracellular antioxidant activity of Zein/Chitosan nanoparticles incorporated with quercetin. Journal of Agricultural and Food 
Chemistry. https://doi.org/10.1021/acs.jafc.8b04571

Mahady, G. B., \& Pendland, S. L. (2000). Resveratrol inhibits the growth of helicobacter pylori in vitro. The American Journal of Gastroenterology, 95, 1849-1849.

Maikoparova, S. C. (2010). Pathogenic Basis for the inclusion of dihydroquercetin in complex treatment of patients with breast cancer. Doctoral dissertation. Nizhny Novgorod Medical Academy, Nizhny Novgorog, Russia.

Martin, H. D., Jager, C., Ruck, C., \& Schmidt, M. (1999). Anti and pro-oxidant properties of carotenoids. Journal fur Praktische Chemie, 341, 302-308.

Martínez, L., Ros, G., \& Nieto, G. (2018). Hydroxytyrosol: health benefits and use as functional ingredient in meat, Medicines, 5, 13. https://doi.org/10.3390/medicines501001

Maslov, M. Y., Plotnikova, T. M., Anishchenko, A. M., Aliev, O. I., Nifantiev, N. E., \& Plotnikov, M. B. (2016). Hemorheological effects of secoisolariciresinol in ovariectomized rats, Biorheology, 53, 23-31. https://doi.org/10.3233/BIR-15066

Matsumoto, K., Yamada, H., Takuma, N., Niino, H., \& Sagesaka, Y. M. (2011). Effects of green tea catechins and theanine on preventing influenza infection among healthcare workers: a randomized controlled trial. BMC Complementary and Alternative Medicine, 11, 15. https://doi.org/10.1186/1472-6882-11-15

Medina, E., De Castro, A., Romero, C., \& Brenes, M. (2006). Comparison of the concentrations of phenolic compounds in olive oils and other plant oils: correlation with antimicrobial activity. Journal of Agricultural and Food Chemistry, 54, 4954-4961. https://doi.org/10.1021/jf0602267

Merola, N., Castillo, J., Benavente-García, O., Ros, G., \& Nieto, G. (2017). The effect of consumption of citrus fruit and olive leaf extract on lipid metabolism. Nutrients, 9, 1062.

Miki, H., Uehara, N., Kimura, A., Sasaki, T., Yuri, T., Yoshizawa, K., \& Tsubura, A. (2012). Resveratrol induces apoptosis via ROS-triggered autophagy in human colon cancer cells. International Journal of Oncology, 40(4), 1020-1028. https://doi.org/10.3892/ijo.2012.1325

Moreno-Franco, B., Garcia-Gonzalez, A., Montero-Bravo, A. M., Iglesias-Gutierrez, E. Ubeda, N., Maroto-Nunez, L., Adlercreutz, H., \& Penalvo, J. L. (2011). Dietary alkylresorcinols and lignans in the Spanish diet: development of the alignia database. Journal of Agricultural and Food Chemistry, 59, 9827-9834. https://doi.org/10.1021/jf2015446

Murata, K., Oyagi, A., Takahira, D., Tsuruma, K., Shimazawa, M., Ishibashi, T., \& Hara, H. (2012). Protective effects of astaxanthin from Paracoccus carotinifaciens on murine gastric ulcer models. Phytotherapy Research, 26, 1126-1132. https://doi.org/10.1002/ptr.3681

Myung, S. K., Bae, W. K., Oh, S. M., Kim, Y., Ju, W., Sung, J., Lee, Y. J., Ko, J. A., Song, J. I., \& Choi, H.J. (2009). Green tea consumption and risk of stomach cancer: A meta-analysis of epidemiologic studies. International Journal of Cancer, 124, 670-677. https://doi.org/10.1002/ijc.23880

Naguib, Y. M. A. (2000). Antioxidant activities of astaxanthin and related carotenoids. Journal of Agricultural and Food Chemistry, 48, 1150-1154. https://doi.org/10.1021/jf991106k

Nemzer, B. V., Yashin, Y. I., \& Yashin, A. Y. (2013). The issues of antioxidant therapy. American Journal of Biomedical. Sciences, 5, 80-108. https://doi.org/10.5099/aj130200080

Nimse S. B., \& Pal, D. (2015). Free radicals, natural antioxidants, and their reaction mechanism. RSC Advances, 5, 27986-28006. https://doi.org/10.1039/C4RA13315C

Ogunleye, A. A., Xue, F., \& Michels, K. B. (2010). Green tea consumption and breast cancer risk or recurrence: a meta-analysis. Breast Cancer Research and Treatment, 119, 477-484. https://doi.org/10.1007/s10549-009-0415-0

Olson, J. A. (2004). Carotenoids: absorption, transport, and metabolism of carotenoids in humans. Pure and Applied Chemistry, 66, 1011-1016.

Oroian, M., \& Escriche, I. (2015). Antioxidants: characterization, natural sources, extraction and analysis. Food Research International, 74, 10-36. https://doi.org/10.1016/j.foodres.2015.04.018

Omoni, A. O., \& Aluko, R. E. (2005). The anti-carcinogenic and anti-atherogenic effects of lycopene: a review. Trends Food Science and Technology, 16(8), 344-50. http://dx.doi.org/10.5772/48134

Palozza, P., Torelli, C., Boninsegna, A., Simone, R., Catalano, A., Mele, M. C., \& Picci, N. (2009). 
Growth-inhibitory effects of the astaxanthin-rich alga Haematococcus pluvialis in human colon cancer cells. Cancer Letter, 283, 108-117. https://doi.org/10.1016/j.canlet.2009.03.031

Pang, J., Zhang, Z., Zheng, T., Yang, Y. J., Li, N., Bain, M., Peng, Y., Zhang, J., Li, Q., \& Zhang, B. (2015). Association of green tea consumption with risk of coronary heart disease in Chinese population. International Journal of Cardiology, 179, 275-278.

Pandelidou, M., Dimas, K., Georgopoulos, A., Hatziantoniou, S., \& Demetzos, C. (2011). Preparation and characterization of lyophilised egg PC liposomes incorporating curcumin and evaluation of its activity against colorectal cancer cell lines. Journal of Nanoscience and Nanotechnology, 11, 1259-66

Park, J. S. Chyun, J. H., Kim, Y. K., Line, L. L., \& Chew, B. P. (2010). Astaxanthin decreased oxidative stress and inflammation and enhanced immune response in humans. Nutrition and Metabolism, 5, 7-18. https://doi.org/10.1186/1743-7075-7-18

Pae, M., \& Wu, D. (2013). Immunomodulating effects of epigallocatechin-3-gallate from green tea: mechanisms and applications. Food and Function, 4, 1287-1303. https://doi.org/10.1039/c3fo60076a

Pawar, Y. B., Purohit, H., Valicherla, G. R., Munjal, B., Lale S. V., Patel, S. B., \& Bansal, A. K. (2012). Novel lipid based oral formulation of curcumin: development and optimization by design of experiments approach. International Journal of Pharmaceutics, 436, 617-23. https://doi.org/10.1016/j.ijpharm.2012.07.031

Peng S. F., Lee C. Y., Hour M. J., Tsai S. C., Kuo D. H., Chen F. A., Shieh, P. C., \& Yang, J. S. (2014). Curcumin-loaded nanoparticles enhance apoptotic cell death of U2OS human osteosarcoma cells through the Akt-Bad signaling pathway. International Journal of Oncology, 44, 238-246. https://doi.org/10.3892/ijo.2013.2175.

Pillow, P. C., Duphorne, C. M., Chang, S., Contois, J. H., Strom, S. S., Spitz, M. R., \& Hursting, S. D. (1999). Development of a database for assessing dietary phytoestrogen intake. Nutrition and Cancer, 33, 3-19. https://doi.org/10.1080/01635589909514742

Pojer, E., Mattivi, F., Johnson, D., \& Stockley, C.S. (2013). The case for anthocyanin consumption to promote human health: a review. Comprehensive Reviews in Food Science and Food Safety, 12, 483-508. https://doi.org/10.1111/1541-4337.12024

Powell, N. (2015). Green tea and health: antioxidant properties, consumption and role in disease prevention; Nova Science Publishers: New York, USA.

Prasad, K. (2009). Flaxseed and cardiovascular health. Journal of Cardiovascular Pharmacology, 54, 369-377.

Preedy, V. R. (2010). Bioactive Foods in Promoting Health; Academic Press: San Diego, USA,

Preedy, V. (2014). Cancer: Oxidative Stress and Dietary Antioxidants; Academic Press: San Diego, USA.

Preedy, V. R. (2014). Diabetes: Oxidative Stress and Dietary Antioxidants; Academic Press: San Diego, USA.

Preedy, V. R. (2014). Aging: Oxidative Stress and Dietary Antioxidants; Academic Press: San Diego, USA.

Preedy, V.R. (2013). Tea in Health and Disease Prevention; Academic Press: San Diego, USA.

Priyadarsini, K. I., Maity, D. K., Naik, G. H., Kumar, M. S., Unnikrishnan, M. K., Satav, J. G., \& Mohan, H. (2003). Role of phenolic O-H and methylene hydrogen on the free radical reaction and antioxidant activity of curcumin. Free Radical Biology and Medicine, 35, 475-484. https://doi.org/10.1016/S0891-5849(03)00325-3

Plotikov, M. B., Aliev, O. I., Maslov, M. J., Vasiliev, A. S., \& Tjukavkina, N. A. (2003). Correction of hemorheological disturbances in myocardial infarction by dihydroquercetin and ascorbic acid. Phytotherapy Research, 17, 86-88. https://doi.org/10.1002/ptr.1113

Plotnikov, M. B., Plotnikov, D. M., Aliev, O.I., Maslov, M. Y., Vasiliev, A. S., Alifirova, V. M., \& Tyukavkina, N. A. (2004). Hemorheological and antioxidant effects of ascovertin in patients with sclerosis of cerebral arteries. Clinical Hemorheology and Microcirculation, 30, 449-452.

Querin, M., Huntley, M. E., \& Olaizola, M. (2003). Haematococcus astaxanthin: applications for human health and nutrition. Trends in Biotechnology, 21, 210-216. https://doi.org/10.1016/S0167-7799(03)00078-7

Rains, T.M., Agarwal, S., \& Maki, K.C. (2011). Antiobesity effects of green tea catechins: a mechanistic review. Journal of Nutritional Biochemistry, 22, 1-7. https://doi.org/10.1016/j.jnutbio.2010.06.006

Rao, A. R., Sindhuja, H. N., Dharmesh, S. M., Sankar, K. U., Sarada R., \& Ravishankar, G. A. (2013). Effective 
inhibition of skin cancer, tyrosinase, and antioxidative properties by astaxanthin and astaxanthin esters from the green alga Haematococcus pluvialis. Journal of Agricultural and Food Chemistry, 61, 3842-3851. https://doi.org/10.1021/jf304609j

Rao, C. V., Rivenson, A., Simi, B., \& Reddy, B. S. (1995) Chemoprevention of colon carcinogenesisby dietary curcumin, a naturally occurring plant phenolic compound. Cancer Research, 55, 259-26.

Renaud, S., \& de Lorgeril, M. (1992). Wine, alcohol, platelets, and the French paradox for coronary heart disease. Lancet, 339(8808), 1523-1526. https://doi.org/10.1016/0140-6736(92)91277-F

Reygaert, W., \& Jusifi, I. (2013). Green tea as an effective antimicrobial for urinary tract infections caused by Escherichia coli. Frontiers in Microbiology, 4, 162. https://doi.org/10.3389/fmicb.2013.00162

Richards L. K. (2014). The most powerful natural antioxidant discovered to date: Hydroxytyrosol. Pro-Health. http://www.prohealth.com/library/print.cfm?libid=17054

Ried, K., \& Fakler, P. (2011). Protective effect of lycopene on serum cholesterol and blood pressure: meta-analyses of intervention trials. Maturitas, 68(4), 299-310. https://doi.org/10.1016/j.maturitas.2010.11.018

Rietjens, I. M., Boersma, M. G., van der Woude, H., Jeurissen, S. M., Schutte, M. E., \& Alink, G. M. (2005). Flavonoids and alkenylbenzenes: mechanisms of mutagenic action and carcinogenic risk. Mutatation Research, 574, 124-138. https://doi.org/10.1016/j.mrfmmm.2005.01.028

Rodríguez-Morató, J., Xicota, L., Fitó, M., Farré, M., Dierssen, M., \& de la Torre, R. (2015). Potential role of olive oil phenolic compounds in the prevention of neurodegenerative diseases. Molecules, 20, 4655-4680. https://doi.org/10.3390/molecules20034655

Russo, M., Spagnuolo, C., Tedesco, I., Bilotto, S., \& Russo, G. L. (2012). The flavonoid quercetin in disease prevention and therapy: facts and fancies. Biochemical Pharmacology, 83, 6-15. https://doi.org/10.1016/j.bcp.2011.08.010

Sabu, M. C., Smitha, K., \& Kuttan, R. (2002). Anti-diabetic activity of green tea polyphenols and their role in reducing oxidative stress in experimental diabetes. Journal of Ethnopharmacology, 83, 109-116. https://doi.org/10.1016/S0378-8741(02)00217-9

Salman, H., Bergman, M., Djaldetti, M., \& Bessler, H. (2007). Lycopene affects proliferation and apoptosis of four malignant cell lines. Biomedicine and Pharmacotherapy, 61(6), 366-369. https://doi.org/10.1016/j.biopha.2007.02.015

Shankar, S., Ganapathy, S., Hingorani, S. R., \& Srivastava, R. K. (2008). EGCG inhibits growth, invasion, angiogenesis and metastasis of pancreatic cancer. Frontiers in Bioscience, 13, 440-452.

Silva, M. M., Santos, M. R., Caroco, G., Rocha, R., Justino, G, \& Mira, L. (2002). Structure-antioxidant activity relationships of flavonoids: a reexamination. Free Radical Research. 36, 1219-1227.

Sarvjeet, S., \& Ashok, K. (2006). Biological effects of curcumin and its role in cancer chemoprevention and therapy. Anticancer Agents in Medicinal Chemistry, 6, 259-270. https://doi.org/10.2174/187152006776930918

Seren, S., Lieberman, R., Bayraktar, U. D., Heath, E. Sahin, K. Andic, F., \& Kucuk, O. (2008). Lycopene in cancer prevention and treatment. American Journal of Therapeutics, 15(1), 66-81. https://doi.org/10.1097/MJT.0b013e31804c7120

Sharmila, G., Bhat, F. A., Arunkumar, R., Elumalai, P., Raja, P. S., Senthlkumar, K., \& Arunakaran, J. (2014). Chemopreventive effect of quercetin, a natural dietary flavonoid on prostate cancer in vivo model. Clinical Nutrition, 33, 718-726. https://doi.org/10.1016/j.clnu.2013.08.011

Singh, R., Akhtar, N., \& Haqqi, T. M. (2010). Green tea polyphenol epigallocatechin-3-gallate: inflammation and arthritis. Life Science, 86, 907-918. https://doi.org/10.1016/j.lfs.2010.04.013

Signorelli, P., \& Ghidoni, R. (2005). Resveratrol as an anticancer nutrient: molecular basis, open questions and promises. Journal of Nutritional Biochemistry, 16(8), 449-466. https://doi.org/10.1016/j.jnutbio.2005.01.017

Stoicov, C., Saffari, R., \& Houghton, J. M. (2009). Green tea inhibits Helicobacter growth in vivo and in vitro. International Journal of Antimicrobial Agents, 33(5), 473-478. https://doi.org/10.1016/j.ijantimicag.2008.10.032 
Stahl, W., \& Sies, H. (1992). Uptake of lycopene and its geometrical isomers is greater from heat-processed than from unprocessed tomato juice in humans. Journal of Nutrition, 122, 2161-2166. https://doi.org/10.1093/jn/122.11.2161

Sun, L., Luo, C., \& Liu, J. (2014). Hydroxytyrosol induces apoptosis in human colon cancer cells through ROS generation. Food \& Function, 5, 1909-1914. https://doi.org/10.1039/c4fo00187g

Tachibana, H. (2009). Molecular basis for cancer chemoprevention by green tea polyphenol EGCG. Forum of Nutrition, 61, 156-169. https://doi.org/10.1159/000212748

Teselkin, Y. O., Zhambalova, B. A., Babenkova, I. V., Klebanov, G. I., \& Tukavina, N. A. (1996). Antioxidant properties of dihydroquercetin. Biophysics, 41, 620-624.

Thazhath, S. S, Wu, T., Bound, M. J., Checklin, H. L., Standfield, S., Jones, K. L., Horowitz, M., \& Rayner, C. K. (2016). Administration of resveratrol for $5 \mathrm{wk}$ has no effect on glucagon-like peptide 1 secretion, gastric emptying, or glycemic control in type 2 diabetes: a randomized controlled trial. American Journal of Clinical Nutrition, 103(1), 66-70. https://doi.org/10.3945/ajcn.115.117440

Thompson, L. U., Boucher, B. A., Liu, Z., Cotterchio, M., \& Kreiger, N. (2006). Phytoestrogen content of foods consumed in Canada, including isoflavones, lignans, and coumestan. Nutrition and Cancer, 54, 184-201. https://doi.org/10.1207/s15327914nc5402_5

Topal, F., Nar, M., Gocer, H., Kalin, P., Kocyigit, U. M., Gulcin, I., \& Alwasel, S. H. (2016). Antioxidant activity of taxifolin: an activity-structure relationship. Journal of Enzyme Inhibition and Medicinal Chemistry, 31, 674-683. https://doi.org/10.3109/14756366.2015.1057723

Tsang, W., \& Kwok, T. T. (2010). Epigallocatechin gallate up-regulation of miR-16 and induction of apoptosis in human cancer cells. Journal of Nutritional Biochemistry, 21, 140-146. https://doi.org/10.1016/j.jnutbio.2008.12.003

Tuck, K. L., \& Hayball, P. Y. (2002). Major phenolic compounds in olive oil: metabolism and health effects. Journal of Nutrition and Biochemistry, 13, 636-644. https://doi.org/10.1016/S0955-2863(02)00229-2

van Breemen, R. B., \& Pajkovic, N. (2008). Multitargeted therapy of cancer by lycopene. Cancer Letter, 269(2), 339-351. https://doi.org/10.1016/j.canlet.2008.05.016

Vázquez-Velasco, M., Esperanza, D. L., Lucas, R., Gómez-Martínez, S., Bastida, S., Marcos, A., \& Sánchez-Muniz, F. J. (2010). Effects of hydroxytyrosol-enriched sunflower oil consumption on CVD risk factors. British Journal of Nutrition, 105(10), 1448-1452. https://doi.org/10.1017/S0007114510005015

Vidalayur, R., Otani, H., Singal, P. K., \& Maulik, N. (2006). Significance of wine and resveratrol in cardiovascular disease: French paradox revisited. Experimental and Clinical Cardiology, 11, 217-225.

Visioli, F., Bellomo, G., \& Galli, C. (1998). Free radical-scavenging properties of olive oil Polyphenols. Biochemical and Biophysical Research Communications, 247, 60-64. https://doi.org/10.1006/bbrc.1998.8735

Voskoboinikova, I. V., Geodakyan, S. V., \& Tukavkina N. A. (1992). Quantitative determination of dihydroquercetin by HPLC. Pharmacy, 6, 74-75.

Wang, Y., \& Ho, C. T. (2009). Polyphenol chemistry of tea and coffee: a century of progress. Journal of Agricultural and Food Chemistry, 57, 8109-8114. https://doi.org/10.1021/jf804025c

Wang, Z., Li, W., Meng, X., \& Jia, B. (2012). Resveratrol induces gastric cancer cell apoptosis via reactive oxygen species, but independent of sirtuin1. Clinical and Experimental Pharmacology and Physiology, 39, 227-232. https://doi.org/10.1111/j.1440-1681.2011.05660.x

Warleta, F., Quesada, C.S., Campos, M., Allouche, Y., Beltrán, G., \& Gaforio, J. J. (2011). Hydroxytyrosol protects against oxidative DNA Damage in human breast cells. Nutrients, 3, 839-857. https://doi.org/10.3390/nu3100839

Watkins, R., Wu, L., Zhang, C., Davis, R. M., \& Xu, B. (2015). Natural product-based nanomedicine: recent advances and issues. International Journal of Nanomedicine, 10, 6055. https://doi.org/10.2147/IJN.S92162

Webb, A. L., \& McCullough, M. L. (2005). Dietary lignans: potential role in cancer prevention. Nutrition and Cancer, 51, 117-131. https://doi.org/10.1207/s15327914nc5102_1

Whitlock, N. C., \& Baek, S. J. (2012). The anticancer effects of resveratrol: modulation of transcription factors. Nutrition and Cancer, 64(4), 493-502. https://doi.org/10.1080/01635581.2012.667862 
Willför, S. M., Ahotupa, M. O., Hemming, J. E., Reunanen, M. H. T., Eklund, P. C., Sjoholm, R. E., Eckerman, C. S., Pohjamo, S. P., \& Holmbom, B. R. (2003). Antioxidant activity of knotwood extractives and phenolic compounds of selected tree species, Journal of Agricultural and Food Chemistry, 51(26), 7600-7606. https://doi.org/10.1021/jf030445h

Wierzejska, R. (2014). Tea and health - a review of the current state of knowledge. Przeglad Epidemiologiczny, 68, 501-506.

Wilson, P. K., \& Hurst, W. J. (2015). Chocolate and Health: Chemistry, Nutrition and Therapy; The Royal Society of Chemistry: Cambridge, UK.

Wu, L., Ashraf, M. H. N., Marina, F., Wang, R., Paterson, P. G., Ferrie, A., \& Juurlink, B. H. J. (2004). Dietary approach to attenuate oxidative stress, hypertension, and inflammation in the cardiovascular system. Proceedings of the National Academy of Sciences USA, 101(18), 7094-7099. https://doi.org/10.1073/pnas.0402004101

Watson, R. R., Preedy, V. R., \& Zibadi, S. (2014). Polyphenols in Human Health and Disease. Academic Press: San Diego, USA.

Wu, X., Beecher, G. R., Holden, J. M., Haytowitz, D. B., Gebhardt, S. E., \& Prior, R. L. (2004). Lipophilic and hydrophilic antioxidant capacities of common food in the United States. Journal of Agricultural and Food Chemistry, 52, 4026-4037. https://doi.org/10.1021/jf049696w

Xu, J., Wang, J., Deng, F., Hu, Z., \& Wang, H. (2008). Green tea extract and its major component epigallocatechin gallate inhibits hepatitis B virus in vitro. Antiviral Research, 78, 242-249. https://doi.org/10.1016/j.antiviral.2007.11.011

Yallapu M. M., Dobberpuhl M. R., Maher D. M., Jaggi M., \& Chauhan S. C. (2012). Design of curcumin loaded cellulose nanoparticles for prostate cancer. Current Drug Metabolism, 13, 120-128. https://doi.org/10.2174/138920012798356952

Yang, Y., Kim, B., \& Lee, J. Y. (2013). Astaxanthin structure, metabolism and health benefits. Journal of Human Nutrition and Food Science, 1, 1003-1013.

Yahsin, Y. I., Yashin, A. Y., \& Nemzer, B. V. (2015). Cocoa and chocolate as medicine and the "Food of the Gods" (cocoa's chemical composition, antioxidant activity, bioavailability of antioxidants, effects on human health and aging). TramsLit., Moscow, 128. https://doi.org/10.3390/antiox6030070

Yashin, Y. I., Vedenin, A. N., \& Yashin A. Y. (2016). Naturally occurring antioxidants is an integral part of a healthy diet and protection from dangerous diseases. Review. In collected works nutrition and metabolism Vol. 4; Moiseyonok, A. G., Russian Academy of Science: Russia.

Yashin, A. Y., Chernousova, N. I., Trukhanov, A. I., Chertushkin, V. S., \& Freidkina, E. V. (2001). HPLC with amperometric detection for determination of trans- and cis-resveratrol in wines. Winemaking and Viticulture, $6,43$.

Yashin, A. Ya., Yashunskii, D. B., Vedenin, A. N., Nifant'ev, N. E., Nemzer, B. V., \& Yashin, Y. I. (2018). Chromatographic determination of lignans (Antioxidants) in food products, Journal of Analytical Chemistry, 73, 399-406.

Yashin, A. Y., Vedenin, A. N., Yashin, Y. I., Yashunsky, D. V., Nifantiev, N. E., \& Nemzer, B. V. (2017). Antioxidant activity of polyphenols from larch wood. An amperometric study, Nutrition and Food Science, 47, 297-303

Yashin, Y. I., Yashin, A. Y., \& Nemzer, B. V. (2013). Beneficial effect of tea on human health. American Journal of Biomedical Sciences, 4, 226-241. https://doi.org/10.5099/aj130400226

Yashin, Y. I., Nemzer, B. V., Ryzhnev, V. Y., Yashin, A. Y., Chernousova, N. I., \& Fedina, P. A. (2010). Creation of a databank for content of antioxidants in food products by an amperometric method. Molecules, 15, 7450-7466. https://doi.org/10.3390/molecules15107450

Yuan, J. P., Peng, J., Yin, K., \& Wang J. H. (2011). Potential health-promoting effects of astaxanthin: a high-value carotenoid mostly from microalgae. Molecular Nutrition and Food Research, 55, 150-165. https://doi.org/10.1002/mnfr.201000414

Yuan, C., Du, L., Jin, Z., \& Xu, X. (2013). Storage stability and antioxidant activity of complex of astaxanthin with hydroxypropyl- $\beta$-cyclodextrin. Carbohydrate Polymers, 91, 385-389. https://doi.org/10.1016/j.carbpol.2012.08.059 
Zarubaev, V., Garshinina, A., \& Kalinina, N. (2010). Anti-influenza activity dihydroquercetin against lethal influenza virus infection. Antiviral Research, 86, A50. https://doi.org/10.1038/aps.2013.54

Zhukova, O. S., Kiselevskii, M. V., Schernbakov, A. M., Fetisova, L. V., Yashunsky, D. V., Tsvetkov, D. E., Menshov, V. M., \& Nifantiev, N. E. (2010). Research of the in vitro effect of a lignan from Abies sibirica (Knotolan $\left.{ }^{\circledR}\right)$ on the growth of hormone-dependent MCF7 breast cancer cells. Cell Technologies in Biology and Medicine, 511-514.

Zhukova, O. S., Kiselevskii, M. V., Schernbakov, A. M., Fetisova, L. V., Yashunsky, D. V., Tsvetkov, D. E., Menshov, V. M., \& Nifantiev, N. E. (2010). Research of the in vitro effect of a lignan from Abies sibirica (Knotolan $\left.{ }^{\circledR}\right)$ on the Growth of Hormone-Dependent MCF7 breast cancer cells. Cell Technologies in Biology and Medicine, 1, 78.

\section{Copyrights}

Copyright for this article is retained by the author(s), with first publication rights granted to the journal.

This is an open-access article distributed under the terms and conditions of the Creative Commons Attribution license (http://creativecommons.org/licenses/by/4.0/). 